\title{
VERBAL 'PREFIXATION' IN THE URALIC LANGUAGES
}

\author{
FERENC KIEFER - LÁSZLÓ HONTI
}

\begin{abstract}
The paper sets out with an overview of preverbs and prefixes in the Uralic languages. It will be shown that most Uralic languages have separable preverbs and only a few have verbal prefixes. These verbal prefixes have been borrowed from Slavic. This means that preverbs never get morphologized in Uralic. We will informally call 'cohesion' the various positions of the preverb relative to the verb. The highest degree of cohesion is the case when the preverb is a genuine prefix; the next degree is represented by adverbial-like preverbs, which obligatorily occupy a preverbal position, and which form a kind of compound with the verb; a yet lower degree is shown by preverbs which can occupy both a preverbal and a postverbal position and some other elements can intervene between the preverb and the base verb; cohesion is greater if only clitical elements can occur between the preverb and the verb. The next stage is represented by the language in which in addition to clitics also some complements can occur in this position. Finally, cohesion is least strong in cases when practically any element can occur between the preverb and the verb. Cohesion should not be confounded with grammaticalization which plays an important role in the development of aspectual and aktionsart-meanings. In this case it can be shown for Hungarian that the development goes through the stages 'adverbial meaning $>$ adverbial meaning and aspectual meaning > aspectual meaning > aspectual meaning and aktionsart-meaning' for the old layer of preverbs and through the stages 'adverbial meaning > adverbial meaning and aspectual meaning > aspectual meaning and aktionsart-meaning' for more recent preverbs. In other words, preverbs may end up by having an aspectual and an aktionsart-meaning' but, as Hungarian shows, not all preverbs have reached this stage.
\end{abstract}

\section{Introduction}

Preverbs are preverbal elements which form a complex verb with the base verb. They can be inseperable in which case they are called verbal prefixes, and separable, in which case they are normally referred to as particles. From among the Uralic languages preverbs can be found in Hungarian (15 million speakers), Vogul or Mansi (3000 speakers), Ostyak or Khanti (14,000 speakers), Livonian (10 speakers), Estonian (1.15 million speakers), Votic (some dozens), Vepsian (3000 speakers), Karelian (138,000 speakers), Finnish (5.15 million speakers) and Selkup (1720 speakers). The North Samoyedic (YurakSamoyed or Nenets, Enisei-Samoyed or Enets, Tavgi-Samoyed or Nganasan,

1216-8076/03/\$20.00 (c) 2003 Akadémiai Kiadó, Budapest 
altogether 30,000 speakers), the Permic (Votyak or Udmurt 500,000 speakers, Zyrjan or Komi 250,000 speakers), the Volgaic (Cheremis or Mari 542,000 speakers, Mordvin 900,000 speakers) languages, Lapp or Saamic (30,000 speakers) and Ingrian (800 speakers $)^{1}$ do not seem to have any preverbs. In the first part of the paper we are going to show that on the basis of their morphological and syntactic behavior the following typology of Uralic preverbs can be established: (a) preverbs are genuine prefixes; (b) preverbs are adverbiallike elements, which obligatorily occupy a preverbal position, and which form a kind of compound with the verb; (c) preverbs can be separated from the base verb by various other elements, and they can also occur in postverbal position; (d) preverbs can be prefixes or adverbial-like elements; in the second case other elements may intervene between the preverb and the verb. We are also going to examine what kind of elements can occur between the preverb and the base verb in the case when the preverb is not a prefix. As will be seen, four different situations are found: (i) there is no restriction either on the number or on the type of elements; (ii) only certain types of elements (object nouns, pronouns, the negative particle) may appear in this position; (iii) only clitics (particles, pronouns) are admitted; (iv) no other element may intervene between the preverb and the verb (but the preverb may be moved to postverbal position). We will informally refer to these four situations as representing four different degrees of cohesion.

We hardly find any genuine verbal prefixes in the Uralic languages; wherever they appear they have either been borrowed from another language (in the case of Livonian, Vepsian and Karelian) or are loan translations (in the case of Finnish). Prefixes can thus not be considered to be the result of morphologization in these languages.

We will also look at the problem of the grammaticalization of the meaning of the preverbs. It will be shown that in the case of the languages under discussion the following situations can be found: (i) preverbs have an adverbial meaning; (ii) they have an adverbial meaning and an associated aspectual meaning (perfectivity); (iii) they have a purely aspectual meaning; (iv) they have developed an Aktionsart-meaning in addition to the aspectual meaning. In the same language preverbs need not exhibit a unified picture, some of them may be characterized by stage (i), others by stage (ii) and again others by stage (iii) or stage (iv). Moreover, the same preverb may - depending on the meaning of the base verb-occur in all four situations. We will say that

1 The figures were taken from Fodor (1999). See also Abondolo (1998).

Acta Linguistica Hungarica 50, 2003 
a language has reached a certain stage if at least some of its preverbs have reached this stage.

Aspect and aktionsart are two related but distinct notions. Aspect has to do with telicity and boundedness whereas aktionsart is - according to the linguistic tradition espoused in the present paper $^{2}$ - a morphosemantic category: it expresses an accidental modification of the meaning of the base verb expressed by morphological means. Aktionsart-meanings include iterativity, resultativity, totality, exhaustivity, diminutivity, etc. Typically, if an aktionsart is expressed by a preverb, the complex verb thus obtained is at the same time perfective, i.e., aktionsart-formation is associated with perfectivization. This is not true in the case of aktionsart-formation by means of suffixation: in that case the aspectual category of the base verb is not changed. ${ }^{3} \mathrm{We}$ have to do with pure aspectual meaning if the only function of the preverb is perfectivization. According to our assumptions, the four situations (i)-(iv) just mentioned represent four different stages in the grammaticalization of the meaning of preverbs: the adverbial preverb develops an aspectual meaning, which slowly becomes the exclusive meaning of the preverb and then, in certain cases, the preverb develops - in addition to the aspectual meaning - an aktionsart-meaning. In the last two cases, i.e., when a preverb expresses an aktionsart ( + perfectivization) or when it expresses just perfectivity, it has no longer any adverbial meaning. ${ }^{4}$

Before embarking on the discussion we have to make clear that we are moving on an extremely uncertain ground and our proposals should be considered as but very preliminary. The reasons for this situation are as follows.

(i) Reliable data are available for a few languages only (Hungarian, Finnish, Estonian, Vogul and Ostyak). In other words, we had to rely on the - in some cases very scarce - material published in various sources (this is particularly true of Livonian, Votic, Vepsian, Karelian and Selkup). One of the consequences of this state of affairs was, then, that if we did not find any

2 Cf., for example, Isačenko (1962), Schlachter (1968), Steinitz (1981), and the references in Steinitz (1981).

3 For example, in Hungarian both imperfective and perfective verbs can take the iterative suffix -gat/-get without any change in aspect. The only exception among the Uralic languages is Nganasan where the base is perfective and all aspectual categories are introduced by suffixation. In that language the durative and the iterative, and perhaps also the habituative suffix, turn the perfective base into an imperfective verb. Cf. Nagy (1995, 269f).

4 In fact, it has no longer any transparent meaning. Compare, for example, the Hungarian preverb $k i$ 'out' with a motion verb such as szalad 'run', which yields kiszalad 'run out', and $k i$ with the aktionsart-meaning 'over' as in kidolgozza magát 'overwork oneself'. 
preverb with aktionsart-meaning, this does not mean that the language does not have such preverbs. Moreover, it was, of course, not possible to work with informants hence there was no way to test our hypotheses.

(ii) The terminology used in the sources is not always transparent and may vary from language to language. In the Finnish tradition, for example, prefixed verbs are called 'compound verbs', in other works the notion of 'verbal prefix' may cover genuine prefixes and adverbial-like preverbal elements alike. Authors normally note that the boundary between prefixes and adverbs is not clear-cut.

The essential question, of course, is not whether a preverbal element has still an adverbial meaning but whether it forms a complex verb with the base verb or not. In the former, but not in the latter case the preverbal element is part of the deverbal derivatives (of the nominalized forms in the first place) and can thus justifiably be called a 'preverb'. Let us illustrate this point with an example taken from Hungarian. The word újra 'again' may appear either as an adverb or as a preverb. Compare (1) and (2).

(1) A könyvet újra olvasom the book-acc again read-1sg 'I am reading the book again.'

(2) A könyvet újra-olvasom the book-acc re-prev-read-1sg 'I am going to reread the book.'

In (1), újra is an adverb, in (2) a preverb (= prev), and it perfectivizes the verb in (2), but not in (1). In other words, (2), but not (1) can be paraphrased as (3) where the verb is prefixed by the perfectivizing preverb el-.

(3) A könyvet újra el-olvasom the book-acc again perf-read-1sg 'I am going to reread the book.'

The preverbal újra has thus two semantic features: 'again' and 'perfective'. Consequently, we are led to the conclusion that uijra is ambiguous between an adverbial and a preverbal reading. Such a polysemy is, however, difficult to detect in languages which have not been thoroughly described. Notice, furthermore, that the nominalized újraolvasás 'rereading' in (4) can only have a perfective reading:

(4) A könyv újra-olvasása nagy örömet okozott 'The rereading of the book was a great pleasure.' 
(iii) The last point concerns diachronic evidence. Morphologization and grammaticalization are diachronic processes. Unfortunately, however, from among the Uralic languages diachronic evidence for morphologization and grammaticalization can be adduced for Hungarian only where the oldest texts date back to the 12th century, and Hungarian words and glosses can be found in even earlier sources (the earliest work which contains data on the Hungarian language is a book on geography written around 930 by an Arab geographer; not much younger is the first Greek source, De administrando imperio, written by the Byzantine emperor Constantine Porphyrogenitus). The first Finnish and Estonian texts stem from the 16th century and are exclusively translations of religious works. What we will have to say about morphologization and grammaticalization of preverbs can therefore be based on Hungarian data alone. To be sure, though similar developments can also be observed in non-Uralic (for example, Slavic) languages, we have to be cautious: the morphologization and grammaticalization processes to be discussed below do not necessarily reflect the historical development in each particular language.

\section{A preliminary typology}

In this section we are going to review the data. In particular, we will seek answers to the following questions: (i) is the preverb separable?, (ii) if so, does it have to occupy a preverbal position and what kind of elements can intervene between the preverb and the base verb?, (iii) can the preverb occur in postverbal position?, (iv) if so, can other elements occur between the base verb and the preverb? As to the function of the preverb, the following questions have to be answered: (i) are the preverbs adverbial-like elements which form a compound with the base verb?, (ii) does the preverb bring about perfectivity?, and, finally, (iii) can the preverb be used to express an aktionsart? As already pointed out, very often we do not have reliable data at our disposal, consequently, the observations presented in this section should be considered tentative.

2.1. Preverbs can be separated from the base verb by various other elements and they can also occur in postverbal position; preverbs can be used for both aktionsart-formation and perfectivization.

This is the situation in Hungarian and Vogul (but not in Ostyak). Compare the following data from Hungarian (5)-(9) and Vogul (10)-(13). 
(5) Péter tegnap ki-ment az erdőbe Peter yesterday out-prev-went the forest-in 'Yesterday Peter went to the forest.'

(6) Péter tegnap ment ki az erdőbe Peter yesterday went out-prev the forest-in 'It was yesterday that Peter went to the forest.'

(7) Ki az erdőbe tegnap ment Péter out-prev the forest-in yesterday went Peter 'To the forest, it was yesterday that Peter went.'

(8) Péter teljesen ki-pihente magát Peter completely out-prev-refresh himself 'Peter completely refreshed himself.'

(9) Ki-takarítok out-prev-tidy-1sg 'I am tidying up.'

In the sentences (5)-(9) we find the preverb $k i$ 'out'; sentences (5)-(7) show various preverbal and postverbal positions of the preverb, in (8) the preverb is used to express the saturative aktionsart (and perfectivity), in (9) just perfectivity. ${ }^{5}$ In (6) the preverb is moved into postverbal position (as a consequence of the focus on tegnap 'yesterday') and in (7) both the place and the time adverbial occur between the preverb and the verb.

Let us next turn to the Vogul examples. ${ }^{6}$

(10) nē man zum kon kals, juw śals woman or man out-prev went in-prev entered

'A woman and a man came out and then went in again.'

(11) taw juw tūp śaltaps he in-prev just entered 'He hardly entered.'

5 Cf. also felmos 'wash up', megföz 'do the cooking', megterít 'set the table', meggyón 'confess', bevásárol 'do some shopping', felszánt 'plough over'. It is unclear how these verbs should be characterized, they certainly do not form a semantically definable class. It should also be made clear that these verbs can only have a clear perfective meaning (without any 'aktionsart'-meaning) if they are conjugated according to the 'indefinite paradigm'. If they take a definite ending they must also have a definite object and perfectivity gets associated with a resultative meaning (implying a change of state) kitakarítok (only implicit object) vs. kitakarítom a szobát 'I am tidying up the room'.

${ }^{6}$ For the Vogul data cf. Munkácsi 1894; Kannisto-Liimola 1956; Rombandeeva 1973.

Acta Linguistica Hungarica 50, 2003 
(12) mińən iń jüw

go-2sg-imp now home/back-prev

'Go home now.'

(13) äwən jil-aylātən

daughter-your down-prev-look-2sg-imp

'Visit your daughter.'

In (10) the preverb stands immediately before the verb, in (11) we find the adverb tup 'just' between the preverb and the verb, and in (12) the preverb occurs in postverbal position. The perfectivizing function of the preverb can be seen in (13). Unfortunately, it was not possible to find examples for preverbs which express an aktionsart (in addition to perfectivity).

2.2. Preverbs can be separated from the base verb by the following elements: particles, pronouns, adverbs; they cannot occur in postverbal position; preverbs have a perfectivizing function.

We find this state of affairs in Ostyak as testified by the following examples: ${ }^{7}$

(14) min jar kata jơ lăyasmôn we-du people house-lat in/back-prev entered-1du 'We went in the house of the people.'

(15) jor t'el ĕntə jöwol home-prev always neg-part comes 'He still does not come home.'

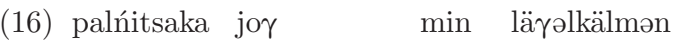
hospital-lat in/back-prev we-du looked-1du 'We dropped into the hospital.'

(17) min mĕnkälmən jo $\gamma$-pa we-du went-1du in/back-prev-part 'We went home.'

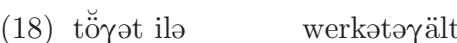
fire away-prev made-3pl 'They made fire.'

In (14) the preverb occupies the position immediately preceding the verb. In (15) we find the negative particle ĕnta and in (16) the personal pronoun min

${ }^{7}$ For the Ostyak data cf. Sauer (1992), Honti (1982), and Tereškin (1961). 
between the preverb and the verb. In (17) the preverb occurs in postverbal position but it is combined with an emphatic particle. Since the preverb can occur in this position only if it is combined with such a particle it seems to be more like an adverb. Consequently, we may safely claim that preverbs in Ostyak cannot occur in postverbal position. In (18) the preverb has a perfectivizing function. Once again, no data could be found with respect to aktionsart-meanings, however, some aktionsart-meanings can be expressed by suffixation: e.g., the suffix - $i$ seems to express the iterative (käri-/kari- 'turn around repeatedly'), the suffix - $m$ the ingressive (kawarma- 'start boiling'), the suffix -əm the semelfactive (kolim- 'cough once') and $-\gamma$ the diminutive aktionsart (posər- 'falling in small drops'). ${ }^{8}$

2.3. Preverbs are adverbial-like elements which normally precede the verb; the adverbial-like preverb and the base verb form a kind of compound; the preverb has neither a perfectivizing nor an aktionsart-forming function, however it may contribute to aspect (aspect is mainly compositional). Some preverbs are genuine prefixes, which cannot be separated from the verb. No other element can intervene between the preverb and the verb.

Finnish exemplifies this situation: ${ }^{9}$

(19) Hän alle-kirjoitti sopimuksen he/she under-prev-wrote agreement

'He/she signed the agreement.'

(20) (a) Politiikot saivat sopimuksen aikaan politicians got agreement prev 'The politicians reached the agreement.'

(b) Politiikot aikaan-saivat sopimuksen Politicians prev-got agreement 'The politicians reached the agreement.'

(21) Hän meni talosta ulos he/she went house-from out-prev 'He/she went out from the house.'

(19) exemplifies the case where Finnish has a preverb (prefix) which cannot be separated from the verb (cf. also aliarvostaa 'underestimate' German unterschätzen, Swedish underskatta, ali 'under'; ylipuhua 'persuade', German

8 Cf. Honti (1984, 53f).

9 For Finnish and Estonian cf. Häkkinen (1987); Hasselblatt (1990); Lavotha (1973); Rätsep (1957); Sulkala (1996); Viitso-Hasselblatt (1992). 
überreden, Swedish övertala, yli 'above'). The most common case is when the position of the preverb is not fixed and the preverb can be moved into postverbal position as in (20a) and (21). If the preverb occupies a preverbal position nothing can intervene between the preverb and the verb. The $a k$ tionsarten are formed by suffixation, and preverbs do not perfectivize, which is a sign that they have preserved their adverbial meaning.

2.4. Preverbs are adverbial-like elements which normally occur in postverbal position; they can be separated from the base verb by other elements; they are never used for aktionsart-formation but they may contribute to aspect (aspect is mainly compositional). The preverb can occur in preverbal position only if the verb is emphatic and occupies the sentence-final position, in that case, however, nothing can intervene between the preverb and the verb.

Estonian and Votic are the languages which belong to this type. Compare the following Estonian examples: ${ }^{10}$

(22) ta üle hinda oma oskusi

he/she up-prev values his/her/own abilities-partitive

'He/she overestimates his/her capacities.'

(23) ma tegin selle töö ära

I did those work away-prev

'I have finished this work.'

In $(22)$ the preverb immediately precedes the verb and nothing can intervene. In (23) the preverb occupies a postverbal position, and, as in (23), in the case of transitive verbs it normally follows the object noun. Once again, the preverb does not perfectivize and it cannot be used to express aktionsarten.

2.5. The preverbs can be genuine prefixes but they can also be adverbial-like elements; in the former case they have a perfectivizing function; other elements may intervene between the adverbial-like preverbs and the base verb (in the first place particles, but also the object noun).

We find this 'mixed' situation in Selkup: ${ }^{11}$

10 Cf. footnote 8 .

11 For the Selkup data cf. Bykonja-Becker (1980); Janurik (1978-1979); Kuznecova et al. (1980). 
(24) ilómdak < ille omdak, pónpáks < pon paks down-prev-sit out-prev-jump

'sit down' 'jump out'

(25) kanak tabep takka mešanet dog squirrel-acc through-prev caught 'The dog caught the squirrel.'

(26) ńєnnä šim īsy

forward-prev me took

'He helped me out.'

(27) əllə pil’əp kätəmbat down-prev dust-acc let down 'The rain has laid the dust.'

(28) ńannä ašša īsyty forward-prev neg-part took 'He has not helped me.'

(29) ńannä sä īläp forward-prev surely help-1sg 'I do help.'

(30) pō-t'ap čāgəmba al'd'emba ілле tree-leaf withered fell down-prev 'The leaves withered and fell down.'

Selkup seems to have some preverbs which are phonologically truncated forms of adverbs and merge with the base verb. This situation is exemplified in (24). In (25) the preverb immediately precedes the verb though it can also occur in postverbal position. In (26) we have a case where the preverb has a perfectivizing function, at the same time a personal pronoun intervenes between the preverb and the verb, in (27) it is the object noun which appears between the preverb and the base verb. In (28) we find the negative particle, in (29) the emphatic particle in this position; finally, in (30) the preverb occupies a postverbal position.

2.6. Preverbs are genuine prefixes, they cannot be separated from the base verb; the prefixes may, but need not have a perfectivizing function.

This type is represented by Livonian, Vepsian and Karelian. ${ }^{12}$ Livonian borrowed prefixed verbs from Latvian, however, the borrowed prefixes are

12 See Pugh (1999); Sivers (1971).

Acta Linguistica Hungarica 50, 2003 
also used productively with native verbs. Vepsian and Karelian borrowed their prefixes from Russian. In Livonian most prefixes have an adverbial function and are not necessarily perfectivizing.

Latvian has eleven verbal prefixes and all of them have been borrowed in Livonian. Very often there is no semantic difference between the prefixed and the prefixless verb. The prefixes have kept their original aktionsartmeaning, e.g., pa-nagrôm 'start laughing' (the ingressive aktionsart), nuosiedõ 'eat up' (the resultative aktionsart). Most prefixes can also be expressed by an adverb, and sometimes a prefix may (redundantly) co-occur with the corresponding adverb.

From among the prefixes which were borrowed from Russian in Vepsian and Karelian the purely perfectivizing po- occurs rarely with native verbs, it is felt semantically 'empty'. It is sometimes omitted even in the case of Russian verbs. We find most often the Russian prefixes do- and pere- with native verbs, e.g., Vepsian dopanda 'reach, place as far as', dosöda 'finish eating', perehüppähtada 'jump across', perepanda 'place across, put over'.

\section{Some conclusions}

As already pointed out, genuine prefixes in Uralic are not the result of historical development: in Finnish they are loan translations (Swedish, German), in Karelian and Vepsian they have been borrowed from Russian, in Livonian they have been taken over from Latvian. Selkup seems to be the only Uralic language in which some traces of strong morphologization of preverbs can be found: (i) there are some examples where the preverb is phonologically reduced (truncated) and merges with the base verb: ilómdak < ille omdak 'sit down'; (ii) the prefixes have a perfectivizing effect: tē wašegu 'fly off'. Selkup thus seems to be the only exception among the Uralic languages, which, at least in some cases, has developed genuine prefixes by morphologization. Since we do not have any historical records on Selkup, however, there is no way to reconstruct the various steps of morphologization.

We saw above that borrowed prefixes (Karelian, Livonian, Vepsian, and we may add here the loan translations in Finnish) do not necessarily perfectivize. On the other hand, the genuine prefixes in Selkup seem to have a perfectivizing function. This observation may justify the conclusion that the main function of prefixes developed from preverbs is perfectivization.

Sentence aspect is compositional in Finnish, Estonian, Votic, Vepsian, Livonian, and Karelian, that is, even if the preverb may contribute to aspect 
it does not determine it fully. On the other hand, aspect is largely lexical in the case of Hungarian, Ostyak, Vogul and Selkup, that is, verbal aspect determines the aspectual value of the sentence completely.

Since Uralic was originally a SXV language, complex verbs have been formed from XV-constituents, this state of affairs is shown by the Ugric languages (Hungarian, Ostyak and Vogul). On the other hand, the coming into being of complex verbs of the type V ADV (Finnish, Estonian) must have occured after the typological change SXV $>$ SVX has taken place, their development is more recent.

Adverbs normally do not perfectivize, this is why Finnish and Estonian complex verbs of the type $\mathrm{V}$ ADV are not perfective, perfectivity is brought about by other means. Aktionsart-formation is possible only if the preverb has completely lost its literal meaning since each aktionsart has a particular meaning, which is in conflict with the original adverbial meaning. Recall the Hungarian example (9), where the preverb $k i$ has no longer anything to do semantically with the adverbial meaning 'out'. This does not mean, of course, that there is no longer any metaphorical link between the original meaning of the preverb and its aktionsart-meaning. In fact, such a link can be shown to exist in the majority of cases. This link is stronger in cases where the aktionsart-meaning has developed from the adverbial meaning directly (see further below). If a preverb expresses an aktionsart, it also expresses perfectivity, which can be explained by looking at the development of aktionsarten (cf. the next section): preverbs either develop first into pure aspect markers and subsequently some of them acquire an aktionsart-meaning, or an aktionsart-meaning develops directly from a perfectivizing adverbial meaning.

Aktionsarten can also be expressed by suffixation. In this case the aspectual value of the verb remains normally unchanged. Finnish, Estonian (and presumably Karelian, Livonian, Vepsian, Votic), and Selkup express aktionsarten by means of suffixation, so does Ostyak. Hungarian, on the other hand, has both preverbs and suffixes which can be used to this end.

As was argued in Kiefer (1997), morphologically expressed aktionsarten seem to be an areal phenomenon: Slavic, Uralic, Georgian constitute the central part of the area. Slavic has more than twenty (the exact number depends on whether productivity is considered a defining criterion of the notion 'aktionsart'), Hungarian eleven aktionsarten. On the other hand, German has a very small number of aktionsarten only (once again, the exact number depends on how the notion is defined) and no (productive) morphological aktionsarten can be found in Romance or English. 
In the next section we will have a look at the development of Hungarian preverbs and their functions. Our findings may then be used to make some claims about the other Uralic languages.

\section{The development of the Hungarian preverbs}

In Hungarian the historical development of the preverbs meg- and el- shows the following stages (these two preverbs developed first). ${ }^{13}$

(i) adverb + directional suffix, normally $e$ or é ('adverbial meaning'), e.g., mëgé 'behind', elé 'forward';

(ii) the preverbs mëgé, elé develop a purely perfectivizing meaning; in this function they are used with certain types of verbs only (mige (1192-1195), mege, ele (1350), e.g., mige szakasztotta 'interrupted', mege lelhesse 'should be able to find'); with verbs of movement the adverbial meaning is combined with aspectual meaning;

(iii) the adverbial meaning disappears (the preverb meg completely loses its original meaning); the first aktionsart-meanings develop (the inchoative with both preverbs: megszomjúhozik 'become thirsty', elkeseredik 'become embittered' (1466); the delimitative-durative with the preverb el-: elélhet 'live for a time', elmunkálkodik 'work' (1492);

(iv) a further aktionsart appears with the preverb meg-: the semelfactive csóvál 'wag' - megcsóvál 'wag once'.

The other preverbs (in the order of their coming into existence until the end of the 15th century: fel 'upwards, up', $k i$ 'out', be 'in', le 'down', alá 'under', össze 'together', many others have developed in later times) have not gone through the same development because with most verbs they have preserved their adverbial meaning. However, $f e l-, k i$ - and $b e$ - have also developed aktionsart-meanings. The development of the meaning of preverbs may thus be generalized for the preverbs meg- and $e l$ - (which have still purely perfectivizing uses) as in (31a) and for the other (more recent) preverbs as in (31b).

(31) (a) adverbial meaning > adverbial meaning and aspectual meaning > aspectual meaning $>$ aspectual and aktionsart-meaning

(b) adverbial meaning $>$ adverbial meaning and aspectual meaning $>$ aspectual and aktionsart-meaning

13 The data are drawn from A historical grammar of Hungarian. Cf. Mátai (1991; 1992). For the historical development of Hungarian preverbs cf. also Honti (1999). 
More recent preverbs, e.g., agyon 'excessively', have undergone the development according to (31b): agyon has an adverbial meaning 'on the head' (e.g., agyon üt originally 'beat on the head'), as a preverb it gets the meaning 'dead' and at the same time perfectivizes the verb, e.g., agyonüt 'beat to death', but in cases such as agyondolgozza magát 'overwork oneself' it carries an aktionsart-meaning. There is no intermediate stage of pure prefective meaning. ${ }^{14}$ At the same time, the metaphorical connection between the literal and the aktionsart-meaning is quite apparent.

From the two clines, (31a) and (31b), the latter seems to be the more plausible and it has also been attested in other languages. ${ }^{15}$ The development of the aktionsart-meaning is quite straightforward. On the other hand, the cline (31a) calls for some explanation. How do we get the aktionsart-meaning from a purely perfectivizing preverb? It can be argued that the aktionsartmeaning is the result of the meaning of the base verb and the perfectivizing effect of the preverb. By way of exemplification let us consider the preverb meg-, which has no descriptive meaning at all. Let us now consider three types of verbs: statives, atelic and telic process verbs; none of these verb types is perfective. If we apply meg- to a stative verb, we get the meaning 'coming about of a state', which is the only way to get a perfective meaning with states, e.g., meg-tud 'to get to know', meg-szeret 'to get to love'. If we use meg- with atelic process verbs, once again the perfective meaning can only refer to the beginning of the process since atelic verbs cannot have an end point, e.g., meg-kondul 'to begin to toll', meg-zendül 'to begin to sound'. The base verbs which can be used with this meaning all belong to the lexical class of verbs of sound emission (with an inanimate source). A special case of atelic verbs is respresented by the class of lexically iterative verbs such as csóvál 'to wag', kavar 'to stir', simogat 'to stroke, to pet', etc. In this case the perfective means 'doing once' (semelfactive): meg-csóvál 'to wag once', meg-kavar 'to stir once', meg-simogat 'to stroke once'. Finally, in the case of telic verbs the use of the perfectivizing prefix results in the resultative aktionsart: the process has reached its end point, or the activity is completed: meg-ir 'to finish writing', meg-varr 'to finish sewing', meg-okosodik 'become prudent/wise'. Similar things can be said about the prefectivizing prefix el-. ${ }^{16}$ It goes without saying that in the case of (31a) no metaphorical link between the aktionsart-meaning and the purely aspectual meaning is possible.

14 For an interesting discussion of this development cf. Ladányi (2000).

15 For example, in Slavic, cf. Regnéll (1944).

16 Cf., for more details, Kiefer-Ladányi (2000, 475-80). 
It can be claimed that (31a) and (31b) are the two clines of the grammaticalization of preverbs. As we saw, among the Uralic languages, Hungarian has reached the highest degree in these clines, Ostyak and Vogul seem to represent the third stage in the cline (31a), and the other Uralic languages which have developed preverbs seem to represent the second stage in that cline. It should be made clear, however, that not all preverbs in a given language have gone through the same development.

We can also establish a cline for grammatical cohesion. In Hungarian and in Vogul (in some dialects) the preverb has the largest freedom, it can occupy practically any position in the sentence and all kinds of elements can intervene between the preverb and the base verb. In Ostyak, on the other hand, the preverb cannot occur in postverbal position and between the preverb and the verb only particles, pronouns, adverbs can occur. The third stage is represented by Finnish and Estonian where the preverb typically occupies the preverbal position but it can also be moved into a postverbal position. However, if it precedes the verb no other element can intervene. Finally, the last stage is shown by Selkup where genuine prefixes may occur. That is, we get the cline (32).

(32) free position > only preverbal position but some elements may occur between the preverb and the base verb > preverbs may occur pre- and postverbally; if they occupy the preverbal position, nothing can intervene between the preverb and the base verb > preverbs are inseparable

It should be made clear, however, that (32) does not necessarily represent the stages in the morphologization of preverbs since no historical data can be adduced in support of such a claim. Moreover, (32) expresses the stages concerning the distance between the preverb and the base verb. As for the freedom of the position of the preverb, it is taken care of by the cline in (33).

(33) free position > preverbs may occur pre- and postverbally; if they occupy the preverbal position, nothing can intervene between the preverb and the base verb $>$ only preverbal position but some elements may occur between the preverb and the base verb $>$ preverbs are inseparable

As pointed out earlier, claiming that Selkup represents the last stage does not mean that all preverbs in Selkup are prefixes. In order to assign a language to a given stage in the cline (32) it suffices to show that at least some of their preverbs exhibit the property characterictic of that stage. To sum up, then, Hungarian and Vogul represent stage one, Ostyak stage two, Finnish and Estonian stage three and Selkup stage four in cline (32). 


\section{References}

Abondolo, Daniel (ed.) 1998. The Uralic languages. Routledge, London.

Bykonja, Valentina V. - Erika G. Becker 1980. Glagol'nye prefiksy v sel'kupskom jazyke. In: Erika G. Becker (ed.) Jazyki i toponimija. Vyp. 7, 86-99. Tomskij gosudarstvennyj pedagogičeskij institut, Tomsk.

Fodor, István (ed.) 1999. A világ nyelvei [The languages of the world]. Akadémiai Kiadó, Budapest.

Häkkinen, Kaisa 1987. Suomen kielen vanhoista ja uusista yhdysverbeistä [On new and old compound verbs in Finnish]. In: Sananjalka 29:7-27.

Hasselblatt, Cornelius 1990. Das estnische Partikelverb als Lehnübersetzung aus dem Deutschen. Veröffentlichungen der Societas Uralo-Altaica 31. Harrassowitz, Wiesbaden.

Honti, László 1982. Vaszjugáni osztják szövegek [Vasyugan Ostyak texts]. Nyelvtudományi Közlemények 84. Akadémiai Kiadó, Budapest.

Honti, László 1984. Chrestomathia Ostiacica. Tankönyvkiadó, Budapest.

Honti, László 1999. Das Alter und die Entstehungsweise der 'Verbalpräfixe' in uralischen Sprachen (unter besonderer Berücksichtigung des Ungarischen). Teil I. und II. Linguistica Uralica 35, 81-97, 161-76. Eesti Teaduste Akadeemia, Tallin.

Isačenko, Alexander V. 1962. Die russische Sprache. Teil I: Formenlehre. Niemeyer, Halle.

Janurik, Tamás 1978-1979. A szölkup névutók, igekötők és határozószók morfológiai típusainak áttekintése [An overview of the morphological types of the Selkup postpositions, verbal prefixes and adverbs]. In: Néprajz és Nyelvtudomány 22-23:49-159.

Kannisto, Artturi - Matti Liimola 1956. Wogulische Volksdichtung gesammelt und übersetzt von A. K. bearbeitet und herausgegeben von M. L. III. Band. Märchen. Mémoires de la Société Finno-Ougrienne 111. Finnisch-Ugrische Gesellschaft, Helsinki.

Kiefer, Ferenc 1997. Verbal prefixation in the Ugric languages from a typological-areal perspective. In: Stig Eliasson - Ernst Håkon Jahr (eds) Language and its ecology. Essays in memory of Einar Haugen. Trends in Linguistics. Studies and Monographs 100, 323-41. Mouton de Gruyter, Berlin \& New York.

Kiefer, Ferenc-Mária Ladányi 2000. Az igekötők [Preverbs]. In: Ferenc Kiefer (ed.) Strukturális magyar nyelvtan 3. Morfológia [A structural grammar of Hungarian 3. Morphology], 453-518. Akadémiai Kiadó, Budapest.

Kuznecova, Ariadna I. - Evgenij A. Helimskij-Elena V. Gruškina 1980. Očerki po sel'kupskomu jazyku. Tazovskij dialekt. Tom I. Izdatel'stvo Moskovskogo universiteta, Moskva.

Ladányi, Mária 2000. Productivity as a sign of category change. The case of Hungarian verbal prefixes. In: Wolfgang U. Dressler - Oskar E. Pfeiffer - Markus PöchträgerJohn R. Rennison (eds) Morphological analysis in comparison, 113-41. John Benjamins, Amsterdam \& Philadelphia.

Lavotha, Ödön 1973. Kurzgefasste estnische Grammatik. Veröffentlichungen der Societas Uralo-Altaica 9. Harrassowitz, Wiesbaden.

Mátai, Mária D. 1991. Az igekötők [Preverbs]. In: Loránd Benkő-Erzsébet E. Abaffy Endre Rácz (eds) A magyar nyelv történeti nyelvtana. 1. kötet: A korai ómagyar kor és elözményei [A historical grammar of Hungarian. Volume 1: Early Old Hungarian and its antecedents], 433-41. Akadémiai Kiadó, Budapest.

Acta Linguistica Hungarica 50, 2003 
Mátai, Mária D. 1992. Az igekötők [Preverbs]. In: Loránd Benkő-Erzsébet E. Abaffy (eds) A magyar nyelv történeti nyelvtana. 2/1. kötet: A kései ómagyar kor: morfematika [A historical grammar of Hungarian. Volume 2/1: Late Old Hungarian: morphematics], 662-95. Akadémiai Kiadó, Budapest.

Munkácsi, Bernát 1894. A vogul nyelvjárások szóragozásukban ismertetve [The inflectional system of Vogul dialects]. Magyar Tudományos Akadémia, Budapest.

Nagy, Beáta B. 1995. A nganaszan igék aspektusáról [On the aspect of Nganasan verbs]. In: Néprajz és Nyelvtudomány $36: 267-83$.

Pugh, Stefan M. 1999. Structural change in Karelian and Vepsian: prefixation. In: Cornelius Hasselblatt - Paula Jääsalmi-Krüger (eds) Europa et Sibiria. Beiträge zur Sprache und Kultur der kleineren finnougrischen, samojedischen und paläosibirischen Völker. Gedenkband für Wolfgang Veenker. Veröffentlichungen der Societas Uralo-Altaica 51, 341-7. Harrassowitz, Wiesbaden.

Regnéll, Carl Göran 1944. Über den Ursprung des slawischen Verbalaspektes. Gleerup, Lund. Rombandeeva, Evdokija I. 1973. Mansijskij (vogul'skij) jazyk. Nauka, Moskva.

Rätsep, Huno 1957. Aspektikategooriast eesti keeles [On the category of aspect in Estonian]. Emakeele Seltsi Aastaraamat 3. Eesti Riiklik Kirjastus, Tallinn.

Sauer, Gert 1992. Zur Verbalpräfigierung im Ostjakischen. In: Pál Deréky - Timothy Riese Marianne Sz. Bakró-Nagy - Péter Hajdú (eds) Festschrift für Károly Rédei zum 60. Geburtstag, 399-402. Institut für Finnougristik der Universität Wien - ELTE BTK Finnugor Tanszék - MTA Nyelvtudományi Intézet, Wien \& Budapest.

Schlachter, Wolfgang 1968. Arbeiten zur strukturbezogenen Grammatik. Fink, München.

Sivers, Fanny de 1971. Die lättischen Präfixe des livischen Verbs. Imprimerie Berger-Levrault, Nancy.

Steinitz, Renate 1981. Der Status der Kategorie 'Aktionsart' in der Grammatik (oder: Gibt es Aktionsarten im Deutschen?). Linguistische Studien. Reihe A. Arbeitsberichte 76. Zentralinstitut für Sprachwissenschaft der DAW, Berlin.

Sulkala, Helena 1996. Expression of aspectual meaning in Finnish and Estonian. In: Mati Erelt (ed.) Estonian: Typological Studies I. Tartu Riikliku Ülikooli Eesti Keele Õppetooli Toimetised 4, 165-225. Tartu Riiklik Ülikool, Tartu.

Tereškin, Nikolaj I. 1961. Očerki dialektov hantyjskogo jazyka. Čast' pervaja. Vahovskij dialekt. Izdatel'stvo AN SSSR, Moskva \& Leningrad.

Viitso, Tiit-Rein - Cornelius Hasselblatt 1992. Das estnische Partikelverb als Lehnübersetzung aus dem Deutschen. In: Linguistica Uralica $28: 55-9$.

Address of the authors:

Ferenc Kiefer

Research Institute for Linguistics

Hungarian Academy of Sciences

Benczúr utca 33.

H-1068 Budapest

Hungary

kiefer@nytud.hu
László Honti

Università di Udine

Dipartimento di Glottologia e Filologia Classica

Via Mazzini 3

I-33100 Udine

Italy

honti.laszlo@dgfc.uniud.it 